\title{
Chlamydiosis in farmed chickens in Slovakia and zoonotic risk for humans
}

\author{
Lenka Čechová1,A-D, Monika Halánová1,A-F, Ingrid Babinská1,C,E, Ol'ga Danišová2,B-C, \\ Martin Bartkovskýz,B-C, Slavomír Marcinčák ${ }^{3, A-C, E}$, Dana Marcinčáková ${ }^{4, A-C}$, \\ Alexandra Valenčáková2,C,E, Lýdia Čisláková1,E-F \\ ${ }^{1}$ Department of Epidemiology, Faculty of Medicine, Pavol Jozef Šafárik University, Košice, Slovakia \\ ${ }^{2}$ Department of Biology and Genetics, University of Veterinary Medicine and Pharmacy, Košice, Slovakia \\ ${ }^{3}$ Department of Hygiene and Food Industry Technology, University of Veterinary Medicine and Pharmacy, Košice, \\ Slovakia \\ ${ }^{4}$ Department of Pharmacology and Toxicology, University of Veterinary Medicine and Pharmacy, Košice, Slovakia \\ A - Research concept and design, B - Collection and/or assembly of data, C - Data analysis and interpretation, \\ $D$ - Writing the article, E-Critical revision of the article, F-Final approval of article
} Čechová L, Halánová M, Babinská I, Danišová O, Bartkovský M, Marcinčák S, Marcinčáková D, Valenčáková A, Čisláková L. Chlamydiosis in
farmed chickens in Slovakia and zoonotic risk for humans. Ann Agric Environ Med. 2018; 25(2): 320-325. doi: 10.26444/aaem/82948

\begin{abstract}
Introduction. Chlamydia psittaci is an obligate intracellular Gram-negative bacterium causing respiratory disease (chlamydiosis) or asymptomatic carriage in poultry. In humans, it is a zoonotic agent of ornithosis/psittacosis. Due to low awareness of the disease and variable clinical presentation, psittacosis is often remains unrecognised as such by general practitioners. Zoonotic transfer occurs through inhalation of contaminated aerosols, and originates from feathers, faecal material and respiratory tract exudates.

Objective. The aim of this study was to investigate chickens for the presence of Chlamydia sp. from pharyngeal and cloacal swabs and review the zoonotic risk for humans.

Materials and method. 138 clinically healthy chickens from farms in Slovakia were examined for the presence of Chlamydia $s p$. The age of the chickens was 6 months. Two different samples were used - pharyngeal swabs and cloacal swabs. Each sample was examined by the molecular PCR method, and in the case of a positive result the identity of the obtained sequences was examined by a BLAST search.

Results. Of the total number of 276 examined samples from 138 chickens, 19 (6.9\%) showed positivity for C. psittaci infection, 12 (8.7\%) which were positive from pharyngeal swabs and 7 (5.1\%) from cloacal swabs. None of the chickens were positive in both samples. Phylogenetic examination of the 19 isolates identified in the study, based on the 23S rRNA gene sequence, revealed that the isolates obtained were identical with C. psittaci, and genetically very close to genotypes B and genotype $\mathrm{E}$.

Conclusion. C. psittaci infections are apparently emerging in chickens. Chicken-processing plant employees should be considered a risk group for human psittacosis. There is a need for higher awareness and for efficient risk assessment and management.
\end{abstract}

\section{Key words \\ Chlamydia, Chlamydia psittaci, chicken, zoonosis, Slovakia}

\section{INTRODUCTION}

Microorganisms in the family Chlamydiaceae are obligate intracellular pathogens of both mammals and birds. The different species in this family infect many hosts, including humans, with variable tissue tropism causing a multiplicity of acute and chronic diseases, from sexually-transmitted infertility to trachoma, respiratory and cardiovascular diseases. According to the most recent taxonomy, the family Chlamydiaceae, with the single genus Chlamydia (C.), currently contains 12 species $[1,2]$. Among them, Chlamydia psittaci is one of the most important zoonotic species from the epidemiological point of view. It is the causative agent of avian chlamydiosis in birds and ornithosis/psittacosis in humans.

Address for correspondence: Monika Halánová, Pavol Jozef Šafárik University in Košice, Faculty of Medicine, Department of Epidemiology, Šrobárova 2, 04180 Košice, Slovak Republic

e-mail: monika.halanova@upjs.sk

Received: 08.11.2017; accepted: 15.01.2018; first published: 23.02.2018
C. psittaci infections have been demonstrated in at least 460 different bird species, spanning 30 different bird orders [3]. The families Psittacidae (cockatoos, parrots, parakeets and lories) and Columbiformes (pigeons) seem to be especially affected. This pathogen is also prevalent in wild birds, pet birds and the pet bird and poultry trades, causing economic losses to the poultry industry [4].

Zoonotic transfer of $C$. psittaci is a threat to poultry workers worldwide $[5,6]$.

Humans have been reported as facing a particular risk for the transmission of $C$. psittaci from birds, with domestic and companion birds considered to represent the main risk $[7,8,9]$. Chickens cohabit with humans in urban and rural areas. This represents a public health problem, because C. psittaci can be transmitted through the inhalation of dust from the dry faeces of birds or contaminated aerosols created from nasal and/or eye secretions [10]. Handling the plumage and tissues of infected birds and, in rare cases, mouth-to-beak contact or biting, represent a zoonotic risk $[11,12]$. 
Although most avian chlamydial infections remain asymptomatic, they can lead to respiratory, enteric and ocular diseases $[3,13,14]$. The symptoms may vary from inapparent to severe, depending on the chlamydial strain, stress condition, age and health status of the avian host. The symptoms in birds include rhinitis, conjunctivitis, nasal discharge, dyspnoea, polyuria, diarrhoea, anorexia, dullness and lethargy [13]. Psittacosis in humans may vary from inapparent to fatal in untreated patients [15]. Symptoms may include high fever accompanied by a relatively low pulse, headache, chills, myalgia, non-productive coughing and difficulty in breathing. The disease is rarely fatal in properly treated patients.

C. psittaci has 9 known genotypes, 7 avian (A - F, E/B) and 2 mammalian (M56 and WC), all of which can be transmitted to humans [16]. Some genotypes have the capability to infect more than one type of host [17]. Reports on C. psittaci outbreaks on chicken farms or on zoonotic transmissions linked to contact with C. psittaci-infected chickens are extremely rare. Thus far, genotypes A, B, C, $\mathrm{D}, \mathrm{F}$ and $\mathrm{E} / \mathrm{B}$ have been found in chickens $[5,6,18,19,20]$. Perhaps chickens seldom become infected, and/or strains infecting chickens are less virulent, presenting a minor risk for humans.

\section{OBJECTIVE}

The aim of this study was to investigate broiler chickens in Slovakia for the presence of Chlamydia sp. from pharyngeal and cloacal swabs, and in the case of a positive result to identify species by the PCR method and review the zoonotic risk for humans.

\section{MATERIALS AND METHOD}

Samples. A total of 138 broiler chickens (Gallus gallus domesticus) of the ROSS 308 breed were examined for the presence of Chlamydia sp. The chickens were placed in the Clinic of Birds, Exotic and Wild Animals of UVMP in Košice, Slovakia. The age of the chickens was 6 weeks, and they were located on a deep litter, in secured and controlled microclimate conditions, in areas where other animals were present (turkeys, pheasants, laying hens, rabbit)..All chickens were fed with the same industrially produced feed mixtures without the addition of antibiotics.

Cloacal and pharyngeal swabs, 2 from each chicken, were collected using sterile cotton swabs. After collection of samples, each swab was placed in a $1.5 \mathrm{ml}$ sterile microtube filled with $0.3 \mathrm{ml}$ sterile saline solution and turned several times; the swab was then removed from the microtube. The prepared samples were stored at $-80^{\circ} \mathrm{C}$ until processed.

Molecular and phylogeny analysis. To identify Chlamydia sp., genomic DNA was extracted using the DNA-sorbAM nucleic acid extraction kit (AmpliSens, Federal State Institution of Science, Moscow, Russia), according to the manufacturer's instructions. Purified DNA was stored at $-20^{\circ} \mathrm{C}$ prior to being used for PCR.

The PCR method was used. PCR amplification was performed using the primers U23Fa (5'-GAT GCC TTG GCA TTG ATA GGC GAT GAA GGA-3') and 23SIGR (5'-
TGG CTC ATC ATG CAA AAG GCA-3'). These primers amplified domain I of the $23 \mathrm{~S}$ rRNA gene. This segment is a signature sequence for chlamydial species, genera and families [21]. U23Fa matches the sequence just after the start of the 23S rRNA gene, and 23SIGR complements the sequence approximately 600 bases downstream.

Reaction mixtures were prepared by mixing $4 \mu \mathrm{l}$ of Taq polymerase HOT FIREPol Blend Master Mix (Solis BioDyne, Estonia), $6 \mu \mathrm{l}$ of template, $0.2 \mu \mathrm{l}$ of each primer and $9.6 \mu \mathrm{l}$ of purified water.

A sample in which the presence of Chlamydia psittaci DNA had been proven in previous examinations, confirmed by sequencing, was used as a positive control.

All reactions were carried out in a BIOMETRA T-Personal Thermocycler. Cycling conditions for PCR were $95^{\circ} \mathrm{C}$ for 13 min for one cycle, followed by 40 cycles at $95^{\circ} \mathrm{C}$ for $20 \mathrm{sec}$, $66^{\circ} \mathrm{C}$ for $60 \mathrm{sec}$, and $72^{\circ} \mathrm{C}$ for $60 \mathrm{sec}$, and a final extension step at $72^{\circ} \mathrm{C}$ for $10 \mathrm{~min}$ for one cycle. PCR products were analysed by electrophoresis of $10 \mu \mathrm{l}$ of each $20 \mu \mathrm{l}$ reaction mixture on $1.5 \%$ agarose gel stained using GoldView stain (SBS Genetech, China), and visualized fragments were compared with the positive control and the 100 bp DNA ladder. Positive samples were sent for sequencing.

The identity of the obtained sequences was examined by a BLAST search [22]. DNA sequence alignments and phylogenetic analysis were conducted using the MEGA5software. Phylogenetic trees were created using alignments performed with the BioEditSequence Aligment Editor by the distance method and NJ (neighbour joining) by the tree-construction method. All ambiguous positions were removed from each sequence pair. The reliability of branches in the trees was assessed using bootstrap analysis with 1,000 pseudo-replicates, with values above $70 \%$ being reported.

Analysis of sequences for constructing a phylogenetic tree also included 18 reference strains, the partial sequence of the 23S rRNA gene of different Chlamydia species from the Gene Bank database, C. felis FP Cello (U68458), C. felis VR 120 (U68457), C. pneumoniae (U68424), C. suis (U68420), C. muridarum (U68436), C. pecorum (U68439), C. avium (NR_121988), C. abortus (U68444), C. caviae (NR_076195), Parachlamydia acanthamoebae (NR_077046), C. psittaci genotype A (AF481052), C. psittaci genotype B (U68448), C. psittaci genotype C (U68450), C. psittaci genotype D (U68419), C. psittaci genotype E (U68454), C. psittaci genotype F (AF481049), C. psittaci genotype WC (U68456), C. psittaci genotype M56 (U68452) and P. marina (AF 245367) was used as the outgroup.

\section{RESULTS}

From the total of 276 cloacal and pharyngeal swabs obtained from 138 chickens included in the study, 19 (6.9\%) showed positivity for chlamydial infection, $12(8.7 \%)$ of which were from pharyngeal swabs and 7 (5.1\%) from cloacal swabs. None of the chickens were positive in both samples - cloacal and pharyngeal swabs. None of the examined chickens had any clinical signs of chlamydial infection.

Phylogenetic analysis of the 23S rRNA gene to construct the phylogenetic tree using 18 reference strains of different Chlamydia species showed that all positive samples obtained were identical with $C$. psittaci, and genetically very close $(92$ - 100\% identity) to genotypes B (U68448) originally isolated 


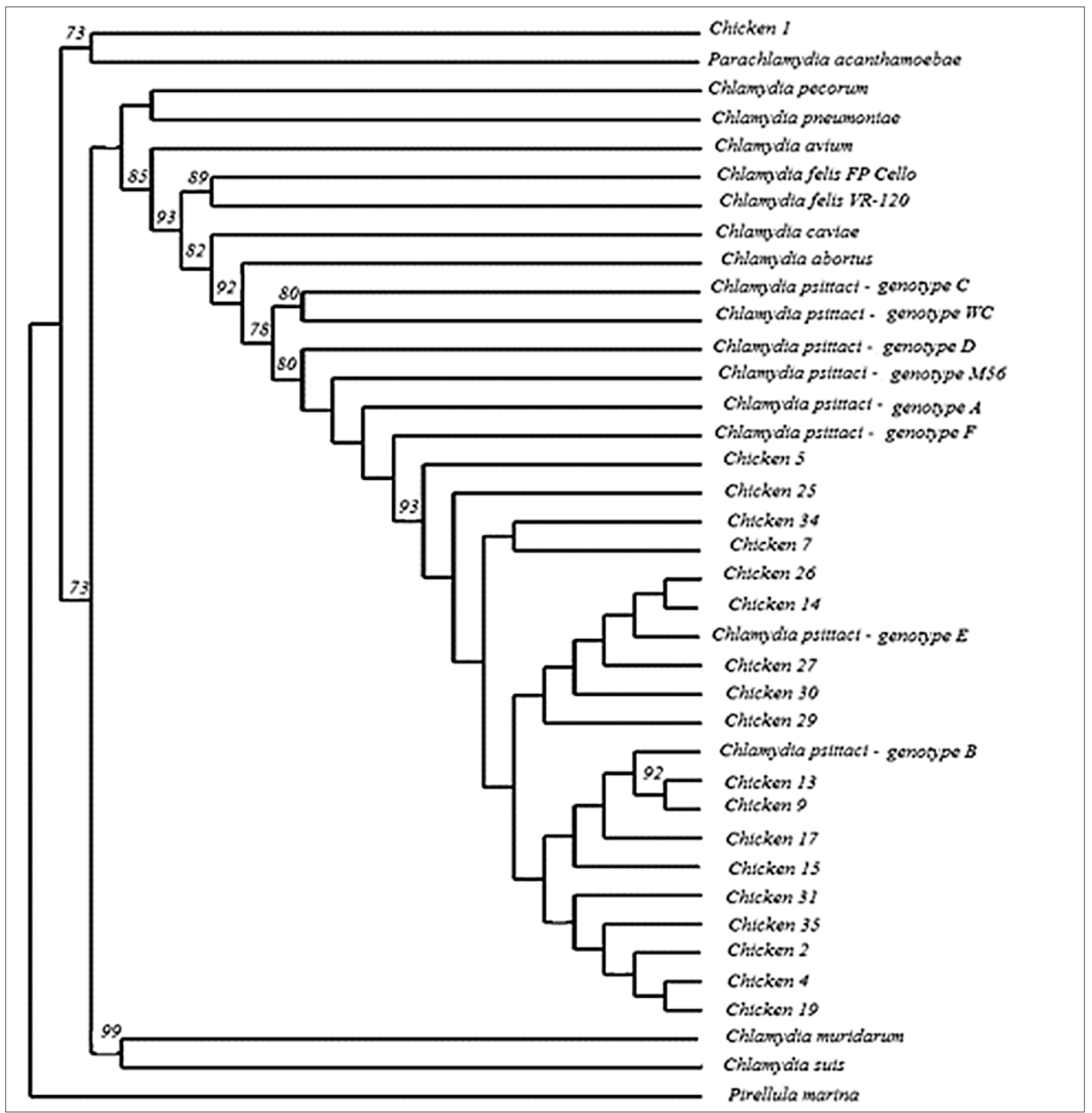

Figure 1. Phylogenetic relationship of the chicken isolates of $C$. psittaci in Slovakia as inferred by neighbour-joining analysis, based on the nucleotide sequences of the $23 \mathrm{~S}$ rRNA gene. Numbers on branches are bootstrap values of 1000 replicates. Bootstrap values above $70 \%$ are shown.

from pigeons and genotype E (U68454), originally isolated from humans with low genetic variability (Fig. 1).

\section{DISCUSSION}

There are 12 closely related and distinct Chlamydia species, and most animals are susceptible to multiple Chlamydia species, often resulting in asymptomatic infections with low bacterial burdens. C. psittaci was considered to be the only pathogenic chlamydial species in birds, but recent evidence suggested that avian chlamydiosis may also involve C. gallinacea, C. avium and C. abortus, as well as C.pecorum or C. trachomatis $[23,24,25,26]$.
C. psittaci has also long been considered the main chlamydial species in poultry. In one study which examined chickens, pigeons, ducks and geese, C. psittaci was the dominant species only in pigeons, while the chlamydial agent C. gallinacea was predominant in chickens. This study indicates that C. gallinacea is the endemic chlamydial species in chickens, whereas $C$. psittaci dominates only in pigeons. The positivity of Chlamydia sp. in the study is considerably higher than in other reports [27].

Recent surveys on the prevalence of C. gallinacea in poultry flocks in 4 European countries and China revealed a prevalence that could even exceed that of $C$. psittaci, at least for chickens and turkeys [28]. These data were recently confirmed by a survey conducted on Chlamydiaceae 
prevalence in slaughtered poultry birds in France, which revealed that $C$. gallinacea was mainly encountered in chickens and turkeys, while $C$. psittaci most often detected in ducks [29].

In the presented study, however, C. psittaci was the predominant chlamydial agent in chickens. A total of 276 samples from 138 asymptomatic chickens as potential source of infection for humans were examined for the presence of Chlamydia sp. by the PCR method, with a $6.9 \%$ prevalence. Higher positivity was observed in samples from the pharynx compared to samples from the cloaca (8.7\% vs. $5.1 \%)$.

Although $C$. psittaci has long been considered the main chlamydial species in poultry, little is known about the current epidemiology and pathology of C. psittaci in chickens. Limited reports from 1960 - 2000 suggest that chickens are less sensitive to C. psittaci infections. However, during the last decade, $C$. psittaci has been detected and isolated from chickens raised in Australia, Belgium, China, France and Germany $[5,8,18,19,30,31,32]$. Dickx et al. (2010) examined Belgian broiler breeder, broiler and layer farms using a C. psittaci recombinant major outer-membrane protein (MOMP)-based antibody ELISA [33], and found 98\%, 95\% and 95\% seropositive layers in broilers and broiler breeders, respectively $[6,32]$.

Less is known about $C$. psittaci genotypes infecting chickens. To-date, genotypes A, B, C, D, F and E/B have been found in chickens $[5,6,18,19,20,34]$. Genotype $A$ is most often found in Psittaciformes (cockatoos, parrots, parakeets and lories) and is frequently transmitted from pet birds to humans. Genotype A has also been isolated from turkeys and wild birds [33, 35, 36]. Thus, the pathogen is not restricted to Psittaciformes and was probably never noticed before in chickens. However, genotypes B and D seem to be most prevalent in chickens, while Genotype D is most often found in turkeys, but recently has been associated with zoonotic transfer from chickens to slaughterhouse employees $[6,21]$. Genotype $\mathrm{C}$ has primarily been isolated from ducks and geese, but has been found once before in chickens, namely in China [18]. Genotype E/B, which was found several swab samples from chicken, was described as being associated mainly with ducks and pigeons, but also humans [5, 37].

Zoonotic transmission to hatchery and abattoir employees did occur, albeit without severe clinical consequences [6, 32]. The prevalence of chlamydial infections in chicken slaughterhouse employees ranged from 6\% - 93.5\%, depending on the diagnostic method used and sample selection techniques applied $[6,34]$. In one of these studies, 25/29 (86.2\%) of humans, all working on C. psittaci-positive farms, reported yearly medical complaints potentially related to psittacosis. Four out of 31 farmers $(12.5 \%)$ had pneumonia after starting to keep chickens, which was higher than the yearly rate of 8 in 1,000 pneumonia cases in Belgium. Many C. psittaci positives were found, but only 4 of them (13.7\%) experienced respiratory diseases (coughing, $n=3$ and/or rhinitis, $n=1$; sinusitis, $n=1$; severe bronchitis, $n=1$ ). They were all infected with genotype $\mathrm{D}$. However, yearly complaints about fever and respiratory disease were of interest. Whether farmers become carriers, the clinical consequences and the importance of co-infections with other human respiratory pathogens are unknown. No potential risk factor, such as age, gender, living in the direct environment of the farm, number of years employed in the sector, daily time in contact with chickens, pets, smoking habit or medical complaints, was significantly related to psittacosis [34]. However, as suggested by Dickx et al. (2010), poultry workers are almost continuously exposed to C. psittaci and therefore could have natural immunity against the disease.

The impact of these C. psittaci infections on human health is difficult to determine. In the USA, Belgium, France, the Netherlands, Germany, Slovakia and the UK, psittacosis is recognized as an occupational disease. In these countries, the occupational physician is obliged to report each case of psittacosis. In most countries, psittacosis is a notifiable disease and must be reported within $48 \mathrm{~h}$. In Slovakia, only 49 cases of ornithosis-psittacosis in humans have been officially reported during the last 15 years (2002-2016) [38]. However, these figures most definitely represent a gross underestimation of the current number of infections, as not all infections cause pneumonia and therefore often remain unnoticed. Moreover, psittacosis is difficult to diagnose in the wake of empirical therapy for community-acquired pneumonia [39, 40].

Preventing avian chlamydiosis in poultry is difficult because of the endemic nature of the bacteria, the long-term survival of the bacteria in organic material, the intermittent shedding and the many asymptomatic carriers [41].

\section{CONCLUSIONS}

Each employer is responsible for the health and safety of his employees and should focus on the prevention of infections. Adequate prevention starts with a risk assessment. The employer, assisted by the occupational physician and occupational hygienist, evaluates the exposure to biological agents, taking into account the nature (contact with people or animals, or the workplace itself), intensity (amount of infectious material handled) and duration of the worker's exposure. The risk assessment must also identify workers and other people who may not be in the workplace all the time (cleaners, maintenance and repair workers, contractors, students on placements) and members of the public who might be present (visitors) [42]. Based on this information, adequate preventive measures can be designed. The second phase is the implementation of the preventive measures. At this stage, education and training of the employees is very important to ensure that the measures are well understood and executed.

Personal protective measures involve a good hand-hygiene protocol and protective clothing, including gloves and an full-face air-filter mask. A transition room should be available where protective clothing may be kept. The 2 most important collective protective measures are ventilation and cleaning. Natural or mechanical ventilation should attempt to prevent aerosol accumulation and cross-contamination between the different barns. Even continuous disinfection of the air in barns could be considered [43].

C. psittaci infections are apparently emerging in chickens. Chicken-processing plant employees should be considered a risk group for human psittacosis. There is a need for higher awareness and for efficient risk assessment and management.

Many health care providers are not familiar with psittacosis, especially with its occupational and zoonotic character. An occupational physician assigned to modern, vertically-integrated poultry farming, covering complete poultry production ranging from the feeding mill to 
processing facilities, could conduct a campaign to raise general awareness and to inform poultry workers about collective and personal protective measures. The occupational physician should address local physicians with a written document, as this may lead to an early diagnosis and treatment in poultry workers [43]. Diagnostic monitoring and reporting of $C$. psittaci infections in poultry workers should be promoted. Criteria defining human cases of psittacosis should be adapted to include nucleic-acid amplification tests (NAATs), which are C. psittaci-specific and extremely sensitive. Psittacosis, whether human or avian, is currently manageable through administration of tetracyclines or macrolides. However, as the use of antibiotics is widespread in the poultry and pet bird industry, the possible emergence of antibiotic resistant zoonotic field strains should be taken into consideration [10]. Additionally, an efficient veterinary vaccine against $C$. psittaci transmission would be beneficial to public health.

\section{Acknowledgements}

This study was supported by the Slovak Research and Development Agency under the contract No. APVV-150134 and No. APVV-14-0397, and by by the Slovak Grant Committee VEGA MŠVVaŠ SR No. 1/0196/15.

\section{REFERENCES}

1. Vorimore F, Hsia RC, Huot-Creasy H, Bastian S, Deruyter L, Passet A, et al. Isolation of a new Chlamydia species from the Feral Sacred Ibis (Threskiornis Aethiopicus): Chlamydia ibidis. PLoS One. 2013; 8(9): e74823.

2. Sachse K, Bavoil PM, Kaltenboeck B, Stephens RS, Kuo Ch, RossellóMóra R, et al. Emendation of the family Chlamydiaceae: Proposal of a single genus, Chlamydia, to include all currently recognized species. Sys App Micro. 2015; 38: 99-103.

3. Kaleta EF, Taday EM. Avian host range of Chlamydophila spp. based on isolation, antigen detection and serology. Avian Pathol. 2003; 32 (5): 435-461.

4. Geigenfeind I, Haag-Wackernagel D. Detection of Chlamydophila psittaci from feral pigeons in environmental samples: problems with currently available techniques. Integr Zool. 2010; 5: 63-69.

5. Gaede W, Reckling KF, Dresenkamp B, Kenklies S, Schubert E, Noack U, et al. Chlamydophila psittaci infections in humans during an outbreak of psittacosis from poultry in Germany. Zoonoses Public Health. 2008; 55: 184-188.

6. Dickx V, Geens T, Deschuyffeleer T, Tyberghien L, Harkinezhad T, Beeckman DS, et al. Chlamydophila psittaci zoonotic risk assessment in a chicken and turkey slaughterhouse. J Clin Microbiol. 2010; 48: 3244-3250.

7. Petrovay F, Balla E. Two fatal cases of psittacosis caused by Chlamydophila psittaci. J Med Microbiol. 2008; 57: 1296-1298.

8. Laroucau K, Vorimore F, Aaziz R, Berndt A, Schubert E, Sachse K. Isolation of a new chlamydial agent from infected domestic poultry coincided with cases of atypical pneumonia among slaughterhouse workers in France. Infect Genet Evol. 2009; 9: 1240-1247.

9. Circella E, Pugliese N, Todisco G, Cafiero MA, Sparagano OA, Camarda A. Chlamydia psittaci infection in canaries heavily infested by Dermanyssus gallinae. Exp Appl Acarol. 2011; 55: 329-338.

10. Beeckman DS, Vanrompay DC. Zoonotic Chlamydophila psittaci infections from a clinical perspective. Clin Microbiol Infect. 2009; 15: $11-17$.

11. Williams J, Tallis G, Dalton C, Ng S, Beaton S, Catton M et al. Community outbreak of psittacosis in a rural Australian town. Lancet. 1998; 351: 1697-1699.

12. Telfer BL, Moberley SA, Hort KP, Branley JM, Dwyer DE, Muscatello DJ, et al. Probable psittacosis outbreak linked to wild birds. Emerg Infect Dis. 2005; 11: 391-397.

13. Vanrompay D, Ducatelle R, Haesebrouck F. Chlamydia psittaci infections: a review with emphasis on avian chlamydiosis. Vet Microbiol. 1995; 45: 93-119.
14. Knittler MR, Berndt A, Böcker S, Dutov P, Hänel F, Heuer D, et al. Chlamydia psittaci: new insights into genomic diversity, clinical pathology, host-pathogen interaction and antibacterial immunity. Int J Med Microbiol. 2014; 304: 877-893.

15. Kovácová E, Majtán J, Botek R, Bokor T, Blaskovicová H, Solavová M, et al. A fatal case of psittacosis in Slovakia, January 2006. Euro Surveill. 2007; 12: E070802.1.

16. Andersen AA, Vanrompay D. 2003. Avian chlamydiosis (psittacosis, ornithosis). Saif YM, ed. Diseases of Poultry, 11th edition, Iowa State University Press, Iowa, USA; 2003. p. 863-879.

17. Andersen AA. Two new serovars of Chlamydia psittaci from North American birds. J Vet Diagn Invest. 1997; 9: 159-164.

18. Zhang F, Li S, Yang J, Pang W, Yang L, He C. Isolation and characterization of Chlamydophila psittaci isolated from laying hens with cystic oviducts. Avian Dis. 2008; 52: 74-78.

19. Zhou J, Qiu C, Lin G, Cao X, Zheng F. Isolation of Chlamydophila psittaci from laying hens in China. Vet Res. 2010; 3: 43-45.

20. Yin L, Kalmar ID, Lagae S, Vandendriessche S, Vanderhaeghen W, Butaye P, et al. Emerging Chlamydia psittaci infections in the chicken industry and pathology of Chlamydia psittaci genotype B and D strains in specific pathogen free chickens. Vet Microbiol. 2013; 162: 740-749.

21. Everett KDE, Bush RM, Andersen AA. Emended description of the order Chlamydiales, proposal of Parachlamydiaceae fam. nov. and Simkaniaceae fam. nov., each containing one monotypic genus, revised taxonomy of the family Chlamydiaceae, including a new genus and five new species, and standards for the identification of organisms. Inter J Syst Bacter. 1999; 49: 415-440.

22. Basic Local Alignment Search Tool. NCBI National Center for Biotechnology Information.https://blast.ncbi.nlm.nih.gov/Blast. cgi?PROGRAM=blastn\&PAGE_TYPE =BlastSearch\&LINK_ LOC=blasthome (accsess 2017.04.15)

23. Sachse K, Laroucau K, Riege K, Wehner S, Dilcher M, Creasy HH, et al. Evidence for the existence of two new members of the family Chlamydiaceae and proposal of Chlamydia avium sp. nov. and Chlamydia gallinacea sp. nov. Syst Appl Microbiol. 2014; 37: 79-88.

24. Sachse K, Laroucau K. Avian chlamydiosis: two more bacterial players discovered. Vet J. 2014; 200: 347-348.

25. Pantchev A, Sting R, Bauerfeind R, Tyczka J, Sachse K. New real-time PCR tests for species-specific detection of Chlamydophila psittaci and Chlamydophila abortus from tissue samples. Vet J. 2009; 181: 145-150.

26. Sachse K, Kuehlewind S, Ruettger A, Schubert E, Rohde G. More than classical Chlamydia psittaci in urban pigeons. Vet Microbiol. 2012; 157: 476-480.

27. Guo W, Li J, Kaltenboeck B, Gong J, Fan W, Wang C. Chlamydia gallinacea, not C. psittaci, is the endemic chlamydial species in chicken (Gallus gallus). Sci Rep. 2016; 6: 19638. doi: 10.1038/srep19638.

28. Zocevic A, Vorimore F, Marhold C, Horvatek D, Wang D, Slavec B, et al. Molecular characterization of atypical Chlamydia and evidence of their dissemination in different European and Asian chicken flocks by specific real-time PCR. Environ Microbiol. 2012; 14: 2212-2222.

29. Hulin V, Oger S, Vorimore F, Aaziz R, de Barbeyrac B, Berruchon J, et al. Host preference and zoonotic potential of Chlamydia psittaci and C. gallinacea in poultry. Pathog Dis. 2015; 73: 1-11. 10.1093/femspd/ ftv005 PMID: 2566334.

30. Yang J, Yang Q, Yang J, He C. Prevalence of avian Chlamydophila psittaci in China. Bulletin of the Veterinary Institute in Pulawy. 2007; 51: 347-350.

31. Robertson T, Bibby S, O’Rourke D, Belfiore T, Agnew-Crumpton $\mathrm{R}$, Noormohammadi AH. Identification of Chlamydial species in crocodiles and chickens by PCR-HRM curve analysis. Vet Microbiol. 2010; 145: 373-379.

32. Dickx V, Vanrompay D. Zoonotic transmission of Chlamydia psittaci in a chicken and turkey hatchery. J Med Microbiol. 2011; 60: $775-779$.

33. Verminnen K, Van Loock M, Hafez HM, Ducatelle R, Haesebrouck F, Vanrompay D. Evaluation of a recombinant enzyme-linked immunosorbent assay for detecting Chlamydophila psittaci antibodies in turkey sera. Vet Res. 2006; 37: 623-632.

34. Lagae S, Kalmar I, Laroucau K, Vorimore F, Vanrompay D. Emerging Chlamydia psittaci infections in chickens and examination of transmission to humans. J Med Microbiol. 2014; 63: 399-407.

35. Van Loock M, Geens T, De Smit L, Nauwynck H, Van Empel P, Naylor $\mathrm{C}$, et al. Key role of Chlamydophila psittaci on Belgian turkey farms in association with other respiratory pathogens. Vet Microbiol. 2005; 107: 91-101.

36. Kalmar ID, Dicxk V, Dossche L, Vanrompay D. Zoonotic infection with Chlamydia psittaci at an avian refuge centre. Vet J. 2013; 199: 300-302. 
37. Geens T, Desplanques A, Van Loock M, Bonner BM, Kaleta EF, Magnino $\mathrm{S}$, et al. Sequencing of the Chlamydophila psittaci ompA gene reveals a new genotype, $\mathrm{E} / \mathrm{B}$, and the need for a rapid discriminatory genotyping method. J Clin Microbiol. 2005; 43: 2456-2461.

38. Čisláková L, Halánová M, Čechová L. Epidemiologická situácia vo výskyte ornitózy-psitakózy u ludí na Slovensku. In: Aktuálne problémy verejného zdravotníctva vo výskume a praxi III. Martin: Jesseniova lekárska fakulta v Martine, Univerzita Komenského v Bratislave. ISBN 9788089797219; 2017. p. 41-46. (in Slovak)

39. Harkinezhad T, Verminnen K, van Droogenbroeck C, Vanrompay D. Chlamydophila psittaci genotype E/B transmission from African grey parrots to humans. J Med Microbiol. 2007; 56: 1097-1100.

40. Pelle-Duporte D, Gendre I. Ornithosis epidemics in a poultry slaughterhouse. INRS, Documents for the occupational physician. 2001; 85: 49-57.
41. Vanrompay D, Harkinezhad T, van de Walle M, Beeckman D, van Droogenbroeck C, Verminnen K, et al. 2007. Chlamydophila psittaci transmission from pet birds to humans. Emerg Infect Dis. 2007; 13: $1108-1110$.

42. HSE. Infection at work: controlling the risks. A guide for employers and the self employed on identifying, assessing and controlling the risks of infection in the workplace. Advisory Committee on Dangerous Pathogens. 2010.

43. Deschuyffeleer TP, Tyberghien LF, Dickx VL, Geens T, Saelen JM, Vanrompay DC, et al. Risk assessment and management of Chlamydia psittaci in poultry processing plants. Ann Occup Hyg. 2012; 56: $340-$ 349 . 